Article

\title{
Termites (Blattodea Latreille 1810, Termitoidae Latreille 1802) of Abuko Nature Reserve, Nyambai Forest Park and Tanji Bird Reserve (The Gambia)
}

\author{
Abdoulaye Baila Ndiaye ${ }^{1, *}$, Ebrima $\mathrm{Njie}^{2}$ and Paul A. Correa ${ }^{2}$ \\ 1 Laboratoire de Zoologie des Invertébrés terrestres, IFAN, UCAD, B. P. 206 Dakar, Sénégal \\ 2 School of Arts and Sciences, Division of Physical and Natural Sciences, University of The Gambia, Brikama \\ Campus, P.O. Box 3530 Serekunda, The Gambia; enjie@utg.edu.gm (E.N.); paul.a.correa@utg.edu.gm (P.A.C.) \\ * Correspondence: abdoulayeb.ndiaye@ucad.edu.sn
}

Received: 6 March 2019; Accepted: 17 April 2019; Published: 28 April 2019

\begin{abstract}
From 28 October to 5 November 2013, a termite study was undertaken in 3 protected sites in The Gambia (West Africa). The aim of the study is to investigate the diversity of termites in three protected areas in the western region of the country. Termite sampling is carried out in $100 \mathrm{~m} \times 2 \mathrm{~m}$ transects that are replicated three (3) times in each site. A total of thirty-one (31) termite species, that belong to fungus growing (11), harvester (1), humuvorous (12) and xylophagous (7), were recorded. The following nineteen (19) species are new to The Gambia: Coptotermes intermedius, Astalotermes near quietus, Ancistrotermes cavithorax, Macrotermes bellicosus, Microtermes grassei, M. lepidus, M. subhyalinus, Odontotermes erraticus, O. pauperans, O. sudanensis, Basidentitermes sp., Euchilotermes tensus arcuata, Noditermes cristifrons, Amitermes evuncifer, Amitermes spinifer, Microcerotermes fuscotibialis, Microcerotermes near parvulus, Microcerotermes near solidus and Promirotermes holmgreni. Additional description and/or ecological information on Odontotermes erraticus, Cubitermes severus, Cubitermes $\mathrm{n}$. proximatus, Euchilotermes tensus arcuata, Basidentitermes sp., and Noditermes cristifrons are given.
\end{abstract}

Keywords: termites; The Gambia; protected site

\section{Introduction}

The termite fauna of The Gambia is still poorly known. One single termite collection trial carried out by Sands in 1966 in the country has been documented [1].

Prior to this date, only one termite species, Odontotermes capensis, referred to as Termes fatalis, was wrongly reported to The Gambia by Walker in 1845 [2]. The occurrence of T. fatalis in both South Africa and The Gambia is objected to by Sjöstedt [3]. The African species referred to as O. capensis is restricted to South Africa and does not occur in The Gambia [4].

From 1950 to 2013, thirty (30) termite species (Table 1) were recorded in The Gambia based on the works of Sands [1,5-7]; Williams \& Perez-Morales [8], Johnson et al. [9] and Krishna et al. [4].

In this study, the objective is to investigate the diversity of termite species and functional groups in the three protected areas of The Gambia, namely Abuko Nature Reserve, Nyambai Forest Park, and Tanji Bird Reserve. 
Table 1. The termite species recorded in The Gambia from 1950 to 2013.

\begin{tabular}{|c|c|c|c|}
\hline Family & Subfamily & Species & African Distribution \\
\hline \multirow{2}{*}{$\begin{array}{l}\text { Kalotermitidae } \\
\text { Froggatt }\end{array}$} & \multirow{2}{*}{$\begin{array}{l}\text { Kalotermitinae } \\
\text { Froggatt }\end{array}$} & Cryptotermes brevis (Walker, 1853) & $\begin{array}{l}\text { RD Congo, The Gambia; Ghana, Madagascar, Nigeria, Senegal, Sierra Leone, South } \\
\text { Africa, Uganda }\end{array}$ \\
\hline & & Cryptotermes havilandi (Sjöstedt, 1900) & $\begin{array}{l}\text { Cameroon; Congo-Brazzaville; RD Congo, Equatorial Guinea, The Gambia, Ghana, } \\
\text { Ivory Coast, Kenya, Madagascar, Mozambique, Namibia, Nigeria, Senegal, Sierra } \\
\text { Leone, South Africa, Swaziland, Tanzania, Zimbabwe. }\end{array}$ \\
\hline Rhinotermitidae & Coptotermitinae & Coptotermes sjostedti Holmgren, 1911 & $\begin{array}{l}\text { Angola, Cameroon, RD Congo, The Gambia, Ghana, Guinea, Ivory Coast, } \\
\text { Mozambique, Nigeria, Senegal, Sierra Leone, Somalia, Sudan, São Tomé and Príncipe, } \\
\text { Tanzania, Uganda }\end{array}$ \\
\hline \multirow{9}{*}{$\begin{array}{l}\text { Termitidae } \\
\text { Latreille }\end{array}$} & \multirow{4}{*}{$\begin{array}{l}\text { Macrotermitinae } \\
\text { Kemner }\end{array}$} & Ancistrotermes crucifer (Sjöstedt, 1897) & $\begin{array}{l}\text { Angola, Cameroon, RD Congo, Ethiopia, The Gambia, Ghana, Guinea, Ivory Coast, } \\
\text { Nigeria, Senegal, Sierra Leone, Togo }\end{array}$ \\
\hline & & Ancistrotermes guineensis (Silvestri, 1912) & Cameroon, The Gambia, Ghana; Guinea, Guinea-Bissau, Ivory Coast, Nigeria, Senegal \\
\hline & & Macrotermes subhyalinus (Rambur, 1842) & $\begin{array}{l}\text { Angola, Benin, Burundi, Central African Republic, Chad, RD Congo, Ethiopia, The } \\
\text { Gambia, Ghana, Guinea, Guinea-Bissau, Ivory Coast, Kenya, Liberia, Malawi, Mali, } \\
\text { Mozambique, Namibia, Nigeria, Rwanda, Senegal, Sierra Leone, Somalia, Sudan, } \\
\text { Tanzania, Togo, Uganda, Zambia, Zimbabwe }\end{array}$ \\
\hline & & Megaprotermes giffardii (Silvestri, 1914) & $\begin{array}{l}\text { Central African Republic, RD Congo, The Gambia, Ghana, Ivory Coast, Nigeria, } \\
\text { Senegal }\end{array}$ \\
\hline & \multirow{5}{*}{$\begin{array}{l}\text { Apicotermitinae } \\
\text { Grassé \& Noirot }\end{array}$} & $\begin{array}{l}\text { Allognathotermes ivorensis Grassé and } \\
\text { Noirot, } 1955\end{array}$ & The Gambia, Guinea, Ivory Coast, Nigeria \\
\hline & & Adaiphrotermes cuniculator Sands, 1972 & The Gambia, Ghana, Nigeria, Senegal \\
\hline & & Aderitotermes cavator Sands, 1972 & Cameroon, The Gambia; Ivory Coast, Nigeria \\
\hline & & $\begin{array}{l}\text { Alyscotermes kilimandjaricus } \\
\text { (Sjöstedt, 1907) }\end{array}$ & $\begin{array}{l}\text { RD Congo, The Gambia, Guinea, Ivory Coast, Kenya, Malawi, Nigeria, South Africa, } \\
\text { Tanzania, Uganda, Zimbabwe }\end{array}$ \\
\hline & & Anenteotermes ateuchestes Sands, 1972 & Cameroon, The Gambia \\
\hline
\end{tabular}


Table 1. Cont.

\begin{tabular}{|c|c|c|c|}
\hline Family & Subfamily & Species & African Distribution \\
\hline & \multirow{4}{*}{$\begin{array}{l}\text { Nasutitermitinae } \\
\text { Hare }\end{array}$} & Eutermellus undulans Sands, 1965 & The Gambia, Ghana, Guinea, Nigeria \\
\hline & & Fulleritermes tenebricus (Silvestri, 1914) & $\begin{array}{l}\text { Central African Republic, RD Congo, Ghana, The Gambia, Guinea, Ivory Coast, } \\
\text { Nigeria, Senegal, Sudan }\end{array}$ \\
\hline & & Nasutitermes arborum (Smeathman, 1781) & $\begin{array}{l}\text { Central African Republic, RD Congo, Ghana, The Gambia, Guinea, Ivory Coast, } \\
\text { Nigeria, Senegal, Sudan }\end{array}$ \\
\hline & & Trinervitermes trinervius (Rambur, 1842) & $\begin{array}{l}\text { Central African Republic, Chad, RD Congo, The Gambia, Ghana, Guinea, } \\
\text { Guinea-Bissau, Ivory Coast, Liberia, Nigeria, Senegal, South Africa, Uganda }\end{array}$ \\
\hline & \multirow{10}{*}{$\begin{array}{l}\text { Cubitermitinae } \\
\text { Weidner }\end{array}$} & Basidentitermes aurivillii (Sjöstedt, 1897) & $\begin{array}{l}\text { Cameroon, Congo-Brazzaville, RD Congo, The Gambia, Ghana, Nigeria, Sudan, } \\
\text { Uganda }\end{array}$ \\
\hline & & Basidentitermes potens Silvestri, 1914 & The Gambia, Guinea, Ivory Coast, Nigeria \\
\hline & & Cubitermes bilobatodes Silvestri, 1912 & The Gambia, Guinea-Bissau, Senegal \\
\hline & & Cubitermes gaigei (Emerson, 1928) & Cameroon, Gabon, The Gambia, Guinea, Ivory Coast, Nigeria \\
\hline & & Cubitermes proximatus Silvestri, 1914 & The Gambia, Guinea \\
\hline & & Cubitermes severus Silvestri, 1914 & The Gambia, Guinea, Ivory Coast, Nigeria, Sudan \\
\hline & & Euchilotermes tensus tensus Silvestri, 1914 & Cameroon, The Gambia, Ghana, Guinea, Ivory Coast, Nigeria, Sierra Leone \\
\hline & & Megagnathotermes notandus Silvestri, 1914 & RD Congo, The Gambia, Guinea, Ivory Coast, Nigeria, Sierra Leone \\
\hline & & Procubitermes sjostedti (Rosen, 1912) & The Gambia, Guinea, Ivory Coast, Liberia, Nigeria, Senegal \\
\hline & & Trapellitermes loxomastax Sands, 1995 & The Gambia, Ghana \\
\hline & \multirow{4}{*}{$\begin{array}{l}\text { Termitinae } \\
\text { Latreille }\end{array}$} & Amitermes guineensis Sands, 1992 & The Gambia, Ghana, Nigeria \\
\hline & & Promirotermes redundans Silvestri, 1914 & The Gambia, Ghana, Guinea, Nigeria, Senegal \\
\hline & & Pericapritermes nigerianus Silvestri, 1914 & Cameroon, The Gambia, Ghana, Nigeria \\
\hline & & Pericapritermes urgens Silvestri, 1914 & Cameroon, The Gambia, Ghana, Guinea, Ivory Coast, Nigeria, Senegal \\
\hline
\end{tabular}




\section{Material and Methods}

\subsection{Study Sites}

The Gambia is a small country in West Africa enclosed by the Senegalese territory except on its Atlantic coast (Figure 1). The climate is characterized by a short rainy season from July to September and a dry season during the rest of the year. From the coast to the inland, the rainfall (900-1300 mm) declines and temperatures increase. In the dry season, the inland regions have an average temperature as high as $35^{\circ} \mathrm{C}$, whilst the average temperature in the coastal regions ranges between $25^{\circ} \mathrm{C}$ and $28{ }^{\circ} \mathrm{C}$. In the wet season, the average temperature can be below $25^{\circ} \mathrm{C}$ at the coast and up to $30{ }^{\circ} \mathrm{C}$ in the inland.

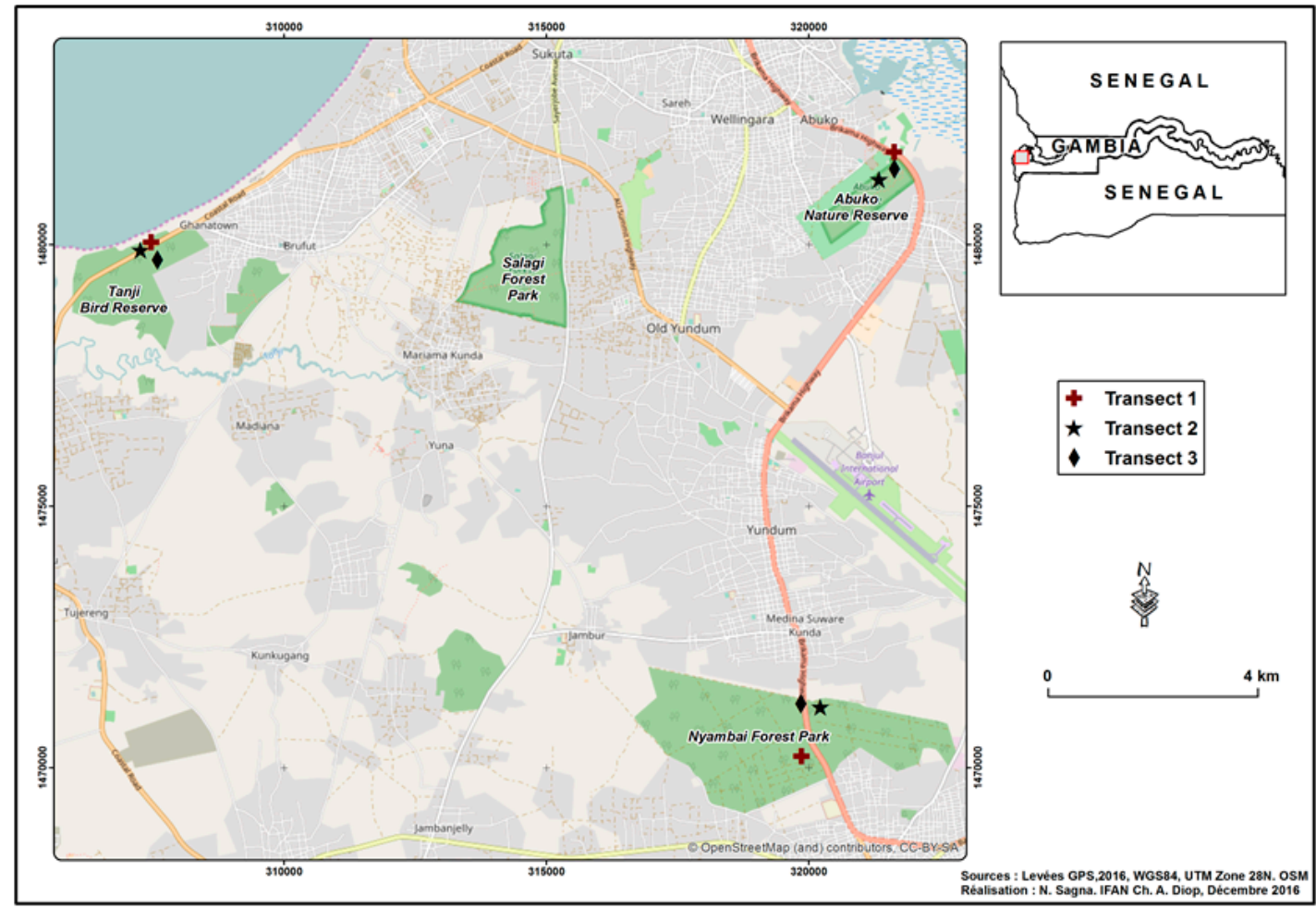

Figure 1. The location of the study sites Abuko Nature Reserve, Tanji Bird Reserve and Nyambai Forest Park.

The Termites were sampled from the Abuko Nature Reserve, Tanji Bird Reserve and the Nyambai Forest Park, which are protected areas in the coastal region (Figure 1).

\subsection{Abuko Nature Reserve}

The Abuko Nature Reserve is located outside the village of Lamin $\left(13^{\circ} 23^{\prime} 00.45^{\prime \prime} \mathrm{N}, 16^{\circ} 38^{\prime} 37.9^{\prime \prime} \mathrm{W}\right)$ in the Kombo North District, about $25 \mathrm{~km}$ away from Banjul. It has been protected as a water catchment area since 1916 and was officially declared a nature reserve in 1968. With a current size of 106 ha, Abuko Nature Reserve is home to a wide diversity of mammals, birds and invertebrates.

Rectangular in shape, the reserve is surrounded by a $300 \mathrm{~m}$ wide buffer zone and it is centered on the Lamin village stream which surfaces within the lower half of the reserve, thereby providing a fairly humid microclimate in the heart of the area. The transect locations are shown in Figure 2.

For most of the year, the central part of the reserve is very humid due to the presence of a dense gallery forest, which surrounds a chain of three (3) pools. Soils are sandy in the periphery of the reserve and sandy/muddy towards the center where the tree canopy forms a continuous shade over the lower vegetation particularly during the wet season. 


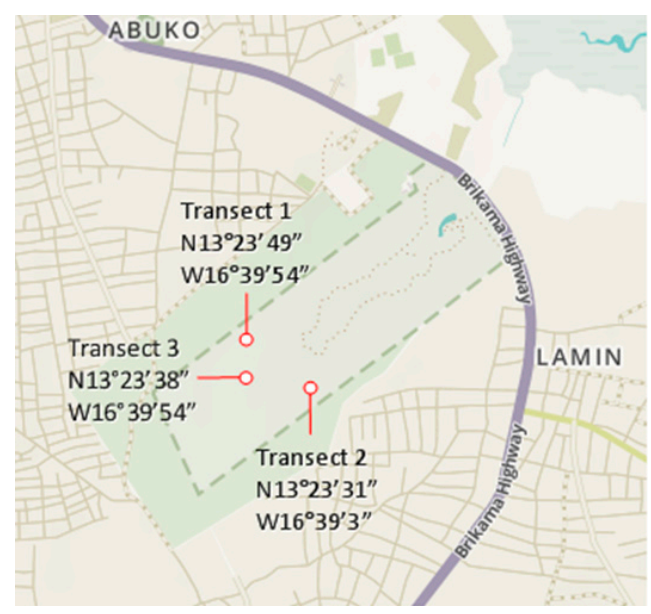

Figure 2. The transects of termite sampling at Abuko Nature Reserve.

Abuko Nature Reserve is among the least disturbed sites of The Gambia where numerous animal species as well plant species continue to be under strong conservation measures.

\subsection{Tanji Bird Reserve}

The Tanji River Bird Reserve is located along the Atlantic Coast in the Western Division, Kombo North. It is a few kilometers away from the fishing village of Ghana town $\left(13^{\circ} 23^{\prime} 06.67^{\prime \prime} \mathrm{N}, 16^{\circ} 46^{\prime} 05.04^{\prime \prime} \mathrm{W}\right)$. The reserve was established in 1993 and covers a surface area of 612 ha $\left(6.12 \mathrm{~km}^{2}\right)$. The three transect locations are shown in Figure 3.

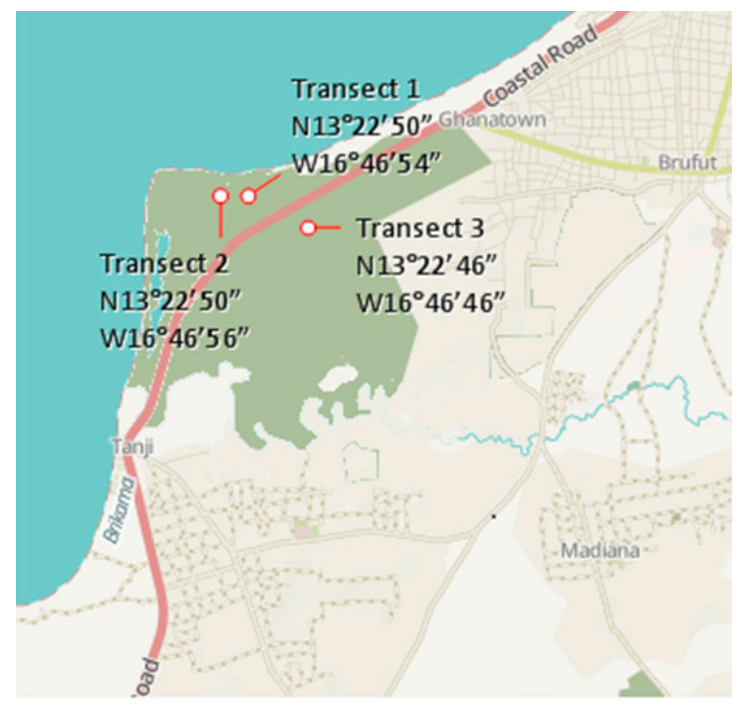

Figure 3. The transect of termite sampling at the Tanji Bird Reserve.

It encompasses the Tanji River and estuary and includes a mangrove ecosystem, coastal dune scrub woodland, and dry woodland savannah. The climate is greatly influenced by the ocean wind.

The northern strip is denser and has a lower canopy height due to previous clearance (transect 1 and transect 2). The southern strip is more open with isolated mature trees as a result of long-term grazing patterns (transect 3). The dominant plant species found are the Ginger Bread Plum, Parinari macrophylla, the Rhun Palm, Borassus aethiopium, and the Baobab, Adansonia digitata. The understorey is generally grass-dominated by the feathery flowered, Perotis indica, the stiff leafed Sporobolus spicatus and the spiny fruited Cenchrus biflorus. A variety of invertebrates populates the reserve, with arthropods being the most abundant. 


\subsection{The Nyambai Forest}

The Nyambai Forest Park is an artificial forest established in 1964. The park was enriched with the Gmelina arborea and Phyllostachys edullus species. It is located at midway between Farato village and Brikama $\left(13^{\circ} 16^{\prime} 29.26^{\prime \prime} \mathrm{N}, 16^{\circ} 38^{\prime} 27.31^{\prime \prime} \mathrm{W}\right)$ about $35 \mathrm{~km}$ from Banjul. The transect locations are shown in Figure 4.

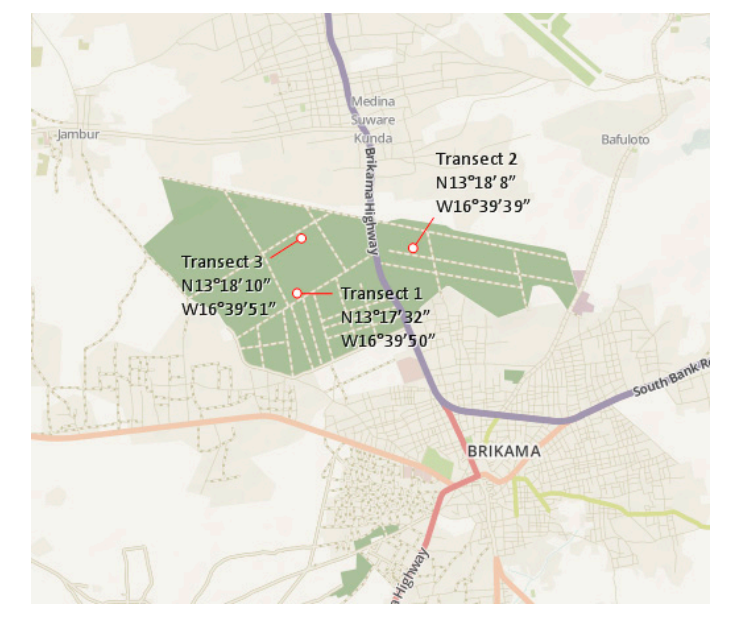

Figure 4. The transects of termite sampling at Nyambai Forest Park.

The vegetation of the forest park is essentially composed of three different species: a spiny shrub vegetation, a tall but thin Gmelina arborea canopy, and a narrow strip of Phyllostachys sp. on the northern side.

The soil is completely covered with a thick layer of litter; a few thriving kinds of grasses grow here and there on the finely sandy to muddy soil. The relative humidity is high in the morning and late in the evening. Monthly average of temperatures range between $17-24{ }^{\circ} \mathrm{C}$ for the minima and $31-33{ }^{\circ} \mathrm{C}$ for the maxima.

\subsection{Sampling Methods}

To standardize sampling effort in the tropical forest areas, Jones \& Eggleton [10] developed a protocol based on a $10 \mathrm{~m} \times 2 \mathrm{~m}$ transect divided into 20 contiguous sections of $5 \mathrm{~m} \times 2 \mathrm{~m}$. Two experienced people sampled each section for $30 \mathrm{~min}$.

In the studied sites, the sampling method, a derivative of the Jones \& Eggleton sampling method, was carried out using a transect ( 3 transects/site) of $100 \mathrm{~m}$ long and $2 \mathrm{~m}$ wide. The transect is not subdivided into sections. The duration of the sampling is not limited but depends on the time required to cover the entire transect. In each transect, the termites are sampled by 3 experienced collectors searching for termites in the soil, litter, dead wood, the stump of trees, beneath the bark of trees, and termite arboreal nests.

The distance between transects ranges from 350 to $700 \mathrm{~m}$ at Abuko, from 360 to $1150 \mathrm{~m}$ at the Nyambai Forest and from 60 to $325 \mathrm{~m}$ at Tanji.

The encountered termite soldiers, workers, swarming individuals, kings, and queens are collected and kept in ethanol 70\% within labeled containers bearing the name of the site, the date, and the micro-habitat.

The voucher specimens are conserved in the entomological collection of IFAN (University of Cheikh Anta Diop University, Dakar, Senegal). The duplicates of the Cubitermes were given to Prof. G. Josens (Université Libre de Bruxelle, Brussels, Belgium) and those of the soldierless termites to Prof. Y. Roisin (Université Libre de Bruxelle, Brussels, Belgium). 


\subsection{Species Identification}

Specimens were observed and photographed using a stereomicroscope (Leica M80) equipped with a camera (Leica IC80 HD) connected to a computer. Leica suite application (Las version 4.2.0) is used for image acquisition and mensuration.

Specimens are compared with reference specimens from the IFAN (Institut fondamental d'Afrique noire) collection identified by W. A. Sands. The reference works by Silvestri [11,12], Sjöstedt [3], Emerson [13], Grassé [14,15], Bouillon \& Mathot [16] and Roy-Noël [17] are used. The works of Sands focusing more on Nasutitermitinae [18] and on the genus Amitermes [19] are also used. Identification of the soldierless species of Apicotermitinae has been made after sands [5,7] on the basis of the morphology of the digestive tube: mesenteron-proctodeum junction and dissected enteric valves are observed under the stereomicroscope. Cubitermes species identification is based on the combination of the morphological characters of soldiers [3,11-13,17] and the shape of the cushions of workers' enteric valves [20]. Enteric valves are dissected and mounted between lamellas, then observed under steromicroscope. Cubitermes species identenfication has been confirmed by Professor G. Josens (ULB, Belgium) who is working on the revision of the genus.

Measurement procedure of head and mandible.

The head width corresponding to the maximum width in the dorsal view.

The head length is measured in the dorsal view from the occiput to the base of the labrum (soldier) or the anterior of the clypeus (worker).

The length of the left mandible is measured in the dorsal view, from the lateral most proximal visible point to the apical point.

\section{Results}

\subsection{Termite Diversity in the Three Sites}

Thirty-one (31) termite species have been recorded in the three sites. They belong to the following two families, six subfamilies and nineteen genera (Table 2).

\subsection{New Termite Species Recorded in The Gambia}

Among the 31 termite species recorded in Abuko Nature Reserve, Nyambai Forest Park and in Tanji Bird Reserve, 19 termite species are recorded newly from The Gambia.

For both subfamilies, Coptotermitinae (Rhinotermitidae) and Apicotermitinae (Termitidae), one newly recorded species has been found, respectively Coptotermes intermedius and Astalotermes near quietus.

In the Macrotermitinae (Termitidae), the 8 newly recorded species from The Gambia are Ancistrotermes cavithorax, Macrotermes bellicosus, Microtermes grassei, M. lepidus, M. subhyalinus, Odontotermes erraticus, O. pauperans and O. sudanensis.

The three new species of Cubiterminae (Termitidae) are Basidentitermes sp., Euchilotermes tensus arcuata and Noditermes cristifrons.

The following six species of Termitinae are new to The Gambia: Amitermes evuncifer, Amitermes spinifer, Microcerotermes fuscotibialis, Microcerotermes near parvulus, Microcerotermes near solidus, Promirotermes holmgreni. 
Table 2. The termite species recorded in the three protected areas in The Gambia. (ANR: Abuko Nature Reserve; NFP: Nyambai Forest Park; TBR: Tanji Bird Reserve; FG: functional group; FGT: fungus growing termites; Ha: harvester termites; Hu: Humuvorous termites; Xylophagous termites).

\begin{tabular}{|c|c|c|c|c|c|c|c|}
\hline Family & Subfamily & Genus & Species & ANR & NFP & TBR & FG \\
\hline $\begin{array}{l}\text { Rhinotermitidae } \\
\text { Froggatt, } 1897\end{array}$ & $\begin{array}{l}\text { Coptotermitinae } \\
\text { Holmgren, } 1910\end{array}$ & Coptotermes Wasmann, 1896 & Coptotermes intermedius Silvestri, 1912 * & $X$ & & & Xyl \\
\hline \multirow{21}{*}{$\begin{array}{c}\text { Termitidae } \\
\text { Latreille, } 1802\end{array}$} & \multirow{2}{*}{$\begin{array}{c}\text { Macrotermitinae } \\
\text { Kemner, } 1934\end{array}$} & \multirow{2}{*}{ Ancistrotermes Silvestri, 1912} & Ancistrotermes cavithorax (Sjöstedt, 1899)* & $x$ & $x$ & $x$ & \multirow{2}{*}{ FGT } \\
\hline & & & Ancistrotermes guineensis (Silvestri, 1912) & $x$ & $x$ & $\mathrm{x}$ & \\
\hline & & \multirow{2}{*}{ Macrotermes Holmgren, 1909} & Macrotermes bellicosus (Smeathman, 1781) * & $X$ & $x$ & $x$ & \multirow{2}{*}{ FGT } \\
\hline & & & Macrotermes subhyalinus (Rambur, 1842) & $x$ & & $x$ & \\
\hline & & \multirow[t]{2}{*}{ Microtermes Wasmann, 1902} & Microtermes lepidus Sjöstedt, 1924 * & $X$ & $X$ & $X$ & \multirow[t]{2}{*}{ FGT } \\
\hline & & & Microtermes subhyalinus Silvestri, 1914 * & $x$ & & $x$ & \\
\hline & & \multirow{3}{*}{ Odontotermes Holmgren, 1910} & Odontotermes erraticus Grassé, 1944 * & & & $\mathrm{X}$ & \multirow{3}{*}{ FGT } \\
\hline & & & Odontotermes pauperans (Silvestri, 1912) * & & $x$ & $X$ & \\
\hline & & & Odontotermes sudanensis Sjöstedt, 1924 * & $X$ & $X$ & $\mathrm{X}$ & \\
\hline & \multirow[t]{4}{*}{$\begin{array}{c}\text { Apicotermitinae } \\
\text { Grassé \& Noirot, } 1955\end{array}$} & Adaiphrotermes Sands, 1972 & Adaiphrotermes near cuniculator Sands, 1972 & \multirow[t]{2}{*}{$x$} & \multicolumn{2}{|l|}{$x$} & $\mathrm{Hu}$ \\
\hline & & Aderitotermes Sands, 1972 & Aderitotermes near cavator Sands, 1972 & & $x$ & & $\mathrm{Hu}$ \\
\hline & & Astalotermes Sands, 1972 & Astalotermes near quietus Sands, 1972 * & $X$ & $x$ & $x$ & $\mathrm{Hu}$ \\
\hline & & Allognathotermes Silvestri, 1914 & Allognathotermes ivorensis Grassé \& Noirot, 1954 & $x$ & & & $\mathrm{Hu}$ \\
\hline & \multirow[t]{2}{*}{$\begin{array}{c}\text { Nasutitermitinae Hare, } \\
1937\end{array}$} & Nasutitermes Dudley, 1890 & Nasutitermes arborum (Smeathman, 1781) & $x$ & & & Xyl \\
\hline & & Trinervitermes Holmgren, 1912 & Trinervitermes trinervius (Rambur, 1842) & $X$ & $X$ & & $\mathrm{Ha}$ \\
\hline & \multirow{6}{*}{$\begin{array}{l}\text { Cubitermitinae } \\
\text { Weidner, } 1956\end{array}$} & \multirow{2}{*}{ Basidentitermes Holmgren, 1912} & Basidentitermes potens Silvestri, 1914 & $x$ & $X$ & $X$ & \multirow{2}{*}{$\mathrm{Hu}$} \\
\hline & & & Basidentitermes sp. * & $x$ & & & \\
\hline & & \multirow{2}{*}{ Cubitermes Wasmann, 1906} & Cubitermes severus Silvestri, 1914 & $x$ & $x$ & $x$ & \multirow{2}{*}{$\mathrm{Hu}$} \\
\hline & & & Cubitermes near proximatus Silvestri, 1914 & $x$ & $x$ & $x$ & \\
\hline & & Euchilotermes Silvestri, 1914 & Euchilotermes tensus arcuata Silvestri, $1914^{*}$ & $\mathrm{X}$ & $X$ & & $\mathrm{Hu}$ \\
\hline & & Noditermes Sjöstedt, 1924 & Noditermes cristifrons (Wasmann, 1911) * & $X$ & $X$ & $X$ & $\mathrm{Hu}$ \\
\hline
\end{tabular}


Table 2. Cont.

\begin{tabular}{|c|c|c|c|c|c|c|c|}
\hline Family & Subfamily & Genus & Species & ANR & NFP & TBR & FG \\
\hline & Termitinae Latreille, 1802 & Amitermes Silvestri, 1901 & $\begin{array}{l}\text { Amitermes evuncifer (Silvestri, 1912)* } \\
\text { Amitermes spinifer (Silvestri, 1914) * }\end{array}$ & $X$ & $X$ & $\begin{array}{l}X \\
X\end{array}$ & Xyl \\
\hline & & Microcerotermes Silvestri, 1901 & $\begin{array}{l}\text { Microcerotermes fuscotibialis (Sjöstedt, 1896) * } \\
\text { Microcerotermes near parvulus (Sjöstedt, 1911) * } \\
\text { Microcerotermes near solidus Silvestri, 1912 * }\end{array}$ & $\begin{array}{l}X \\
X \\
X\end{array}$ & & $\begin{array}{l}X \\
X\end{array}$ & Xyl \\
\hline & & Pericapritermes Silvestri, 1914 & Pericapritermes urgens Silvestri, 1914 & $x$ & $x$ & & $\mathrm{Hu}$ \\
\hline & & Promirotermes Silvestri, 1914 & Promirotermes holmgreni (Silvestri, 1912) * & $x$ & $x$ & & $\mathrm{Hu}$ \\
\hline
\end{tabular}

* New records from The Gambia. 


\subsection{Termite Diversity in Abuko Nature Reserve}

At the Abuko Nature Reserve, 27 species of termites belonging to 2 families and 5 subfamilies were recorded (Table 3). The variable number of the collected species between transects suggests a certain heterogeneity of the termite distribution in the site.

In terms of functional diversity, there is a predominance of the humivorous termites with 11 species followed by the fungus-growing Macrotermitinae which are represented by 9 species. The xylophagous ( 6 species) and the haverster termites ( 1 species) are the least diverse. This type of termite assemblage in Abuko is characteristic of a forestry profile.

\subsection{Termite Diversity in Nyambai Forest Park}

The species richness of termites in Nyambai Forest Park is of 20 species (Table 4). At the functional level, there is still greater diversity of the humivorous termites represented with 12 species followed by the fungus-growing termite ( 8 species). The harvester termites and the xylophagous termites are represented each by 1 species.

The spatial distribution of the termite species is rather heterogeneous: 12 species are recorded in transect 1, 10 species in transect 2 and 16 species in transect 3 . The species richness and spatial distribution heterogeneity in Nyambai Forest are less important than in Abuko and could be associated with the relatively low botanical diversity in this artificial site.

\subsection{Termite Diversity in Tanji Bird Reserve}

At the Tanji Bird Reserve, with 20 species, the species richness is less important than in the other two sites (Table 5). The spatial distribution is also heterogeneous in this site as 15 species are recorded in transect 1, 12 species in transect 2 and 4 species in transect 3.

In terms of functional diversity, the fungus-growing termites (11 species) largely dominate the humivorous (5 species) and the xylophagous (1 species).

\subsection{Additional Information on Some Species}

Based on the frequent confusion and misidentification in the West African Odontotermes and Cubitermes, we give some descriptive information on Odontotermes erraticus, Cubitermes severus and Cubitermes near proximatus. Euchilotermes tensus arcuata, a subspecies described by Silvestri, should be elevated to the rank of species, taking into account the distinctive features used in the description of the species of the genus. Finally, some information is given on Basidentitermes sp. and Noditermes cristifrons. 
Table 3. The termite species collected in different stations in the Abuko Nature Reserve. (Abbreviations: $K=$ king; $Q=q u e e n ; S=$ soldiers; $W=$ workers).

\begin{tabular}{|c|c|c|c|}
\hline Abuko Nature Reserve Species & Transect 1 & Transect 2 & Transect 3 \\
\hline Coptotermes intermedius Silvestri, 1912 & - & Dead wood in the soil $(S, W)$ & - \\
\hline Ancistrotermes cavithorax (Sjöstedt, 1899) & Litter, dead wood, tree $(\mathrm{S}, \mathrm{W})$ & Tree collar $(\mathrm{S}, \mathrm{W})$ & Dead wood $(S, W)$ \\
\hline Ancistrotermes crucifer (Sjöstedt, 1897) & Litter, dead wood, tree, soil $(\mathrm{S}, \mathrm{W})$ & Macrotermes nest wall, dead wood $(\mathrm{S}, \mathrm{W})$ & Stump, dead wood, soil $(\mathrm{S}, \mathrm{W})$ \\
\hline Ancistrotermes guineensis (Silvestri, 1912) & - & Litter $(S, W)$ & - \\
\hline Macrotermes bellicosus (Smeathman, 1781) & Nest $(S, W)$ & Litter, soil $(\mathrm{S}, \mathrm{W})$ & Litter, dead wood $(\mathrm{S}, \mathrm{W})$ \\
\hline Macrotermes subhyalinus (Rambur, 1842) & Dead wood $(S, W)$ & Litter, dead wood, soil $(\mathrm{S}, \mathrm{W})$ & - \\
\hline Microtermes grassei Ghidini, 1955 & Dead wood, soil $(\mathrm{S}, \mathrm{W})$ & Nest, litter, dead wood (S, W) & - \\
\hline Microtermes lepidus Sjöstedt, 1924 & Litter, dead wood, soil, tree, nest $(\mathrm{S}, \mathrm{W})$ & - & - \\
\hline Microtermes subhyalinus Silvestri, 1914 & Dead wood, soil $(\mathrm{S}, \mathrm{W})$ & Dead wood $(S, W)$ & - \\
\hline Odontotermes sudanensis Sjöstedt, 1924 & - & - & Dead palm tree stem $(S, W)$ \\
\hline Adaiphrotermes near cavator & Soil (W) & - & Nest (W) \\
\hline Astalotermes near quietus & Soil (W) & - & Litter $(W)$ \\
\hline Allognathotermes ivorensis Grassé \& Noirot, 1954 & Nest $(S, W)$ & - & - \\
\hline Nasutitermes arborum (Smeathman, 1781) & - & - & Dead wood, tree $(\mathrm{S}, \mathrm{W})$ \\
\hline Trinervitermes trinervius (Rambur, 1842) & - & - & Nest $(\mathrm{S}, \mathrm{W})$ \\
\hline Basidentitermes potens Silvestri, 1914 & Nest $(S, W)$ & Soil $(S, W)$ & - \\
\hline Basidentitermes sp. & Soil $(\mathrm{S}, \mathrm{W})$ & - & - \\
\hline Cubitermes near proximatus Silvestri, 1914 & Nest, Soil (S, W) & Nest $(S, W)$ & - \\
\hline Cubitermes severus Silvestri, 1914 & - & Nest $(S, W)$ & Nest $(S, W)$ \\
\hline Euchilotermes tensus arcuata Silvestri, 1914 & Nest $(S, W)$ & - & - \\
\hline Noditermes cristifrons (Wasmann, 1911) & Nest $(S, W)$ & Nest $(K, Q, S, W)$ & Nest $(S, W)$ \\
\hline Amitermes evuncifer (Silvestri, 1912) & Dead wood $(S, W)$ & - & - \\
\hline Microcerotermes fuscotibialis (Sjöstedt, 1896) & Tree, arboreal nest $(\mathrm{S}, \mathrm{W})$ & Trees $(\mathrm{S}, \mathrm{W})$ & - \\
\hline Microcerotermes near parvulus (Sjöstedt, 1911) & - & - & Tree stump $(S, W)$ \\
\hline Microcerotermes near solidus Silvestri, 1912 & Nest $(S, W)$ & Dead wood $(S, W)$ & - \\
\hline Pericapritermes urgens Silvestri, 1914 & Nest $(S, W)$ & - & Nest $(S, W)$ \\
\hline Promirotermes holmgreni (Silvestri, 1912) & - & Nest $(S, W)$ & Stump, dead wood, nest $(\mathrm{S}, \mathrm{W})$ \\
\hline
\end{tabular}


Table 4. The termite species collected in different stations in Nyambai Forest Park (abbreviations: $K=$ king; $Q=$ queen; $S=$ soldiers; $W=$ workers).

\begin{tabular}{|c|c|c|c|}
\hline Nyambai Forest Park Species & Transect 1 & Transect 2 & Transect 3 \\
\hline Ancistrotermes cavithorax (Sjöstedt, 1899) & Tree, dead wood, litter $(\mathrm{S}, \mathrm{W})$ & Dead wood $(S, W)$ & Tree, dead wood $(S, W)$ \\
\hline Ancistrotermes crucifer (Sjöstedt, 1897) & Tree $(S, W)$ & - & Stump, tree $(\mathrm{S}, \mathrm{W})$ \\
\hline Ancistrotermes guineensis (Silvestri, 1912) & Tree, dead wood $(\mathrm{S}, \mathrm{W})$ & Tree, dead wood, liana, soil $(\mathrm{S}, \mathrm{W})$ & Tree, dead wood, litter, soil (S, W) \\
\hline Macrotermes bellicosus (Smeathman, 1781) & Nest, dead wood, litter $(\mathrm{S}, \mathrm{W})$ & - & Nest, stumps, tree, litter, dead wood, soil $(S, W)$ \\
\hline Microtermes grassei Ghidini, 1955 & - & - & Nest $(\mathrm{S}, \mathrm{W})$ \\
\hline Microtermes lepidus Sjöstedt, 1924 & Tree, dead wood $(S, W)$ & - & Dead wood, soil, nest $(S, W)$ \\
\hline Odontotermes pauperans (Silvestri, 1912) & - & - & Dead wood, soil $(\mathrm{S}, \mathrm{W})$ \\
\hline Odontotermes sudanensis Sjöstedt, 1924 & Tree, litter, dead wood $(\mathrm{S}, \mathrm{W})$ & - & Nest, stump $(\mathrm{S}, \mathrm{W})$ \\
\hline Adaiphrotermes near cuniculator & - & - & Nest, soil (W) \\
\hline Aderitotermes near cavator & Soil (W) & Nest (W) & Runways on tree, soil, nest (W) \\
\hline Astalotermes near quietus & - & Soil (W) & Soil (W) \\
\hline Trinervitermes trinervius (Rambur, 1842) & Soil $(S, W)$ & - & - \\
\hline Basidentitermes potens Silvestri, 1914 & - & Soil $(S, W)$ & - \\
\hline Cubitermes severus Silvestri, 1914 & Nest $(S, W)$ & Nest $(Q, S, W)$ & Nest $(S, W)$ \\
\hline Cubitermes near proximatus Silvestri, 1914 & Nest $(S, W)$ & - & Nest $(S, W)$ \\
\hline Euchilotermes tensus arcuata Silvestri, 1914 & - & - & Nest $(S, W)$ \\
\hline Noditermes cristifrons (Wasmann, 1911) & Soil $(S, W)$ & Nest $(K, Q, S, W)$ & Nest $(S, W)$ \\
\hline Amitermes evuncifer (Silvestri, 1912) & Dead $\operatorname{wood}(S, W)$ & Shrub $(S, W)$ & - \\
\hline Pericapritermes urgens Silvestri, 1914 & - & Nest $(S, W)$ & Nest $(S, W)$ \\
\hline Promirotermes holmgreni (Silvestri, 1912) & - & Nest $(S, W)$ & - \\
\hline
\end{tabular}


Table 5. The termite species collected in different stations in the Tanji Bird Reserve (abbreviations: $\mathrm{S}=$ soldiers; $\mathrm{W}=$ workers).

\begin{tabular}{|c|c|c|c|}
\hline Tanji Bird Reserve Species & Transect 1 & Transect 2 & Transect 3 \\
\hline Ancistrotermes cavithorax (Sjöstedt, 1899) & Stump, soil $(S, W)$ & Dead wood $(S, W)$ & Nest, dead wood $(S, W)$ \\
\hline Ancistrotermes crucifer (Sjöstedt, 1897) & Dead wood $(S, W)$ & - & - \\
\hline Ancistrotermes guineensis (Silvestri, 1912) & Dead wood, soil $(S, W)$ & Litter, dead wood, tree $(\mathrm{S}, \mathrm{W})$ & - \\
\hline Macrotermes bellicosus (Smeathman, 1781) & Tree, soil $(\mathrm{S}, \mathrm{W})$ & Litter, soil $(S, W)$ & Nest, dead wood $(S, W)$ \\
\hline Macrotermes subhyalinus (Rambur, 1842) & Dead wood in soil $(\mathrm{S}, \mathrm{W})$ & - & - \\
\hline Microtermes grassei Ghidini, 1955 & Soil $(S, W)$ & - & - \\
\hline Microtermes lepidus Sjöstedt, 1924 & Dead wood $(S, W)$ & - & - \\
\hline Microtermes subhyalinus Silvestri, 1914 & Dead wood $(S, W)$ & Dead wood, soil $(S, W)$ & - \\
\hline Odontotermes erraticus Grassé, 1944 & - & Preys of Megaponera, soil $(\mathrm{S}, \mathrm{W})$ & - \\
\hline Odontotermes pauperans (Silvestri, 1912) & - & Nest, dead wood $(S, W)$ & Soil $(S, W)$ \\
\hline Odontotermes sudanensis Sjöstedt, 1924 & - & Nest, soil $(\mathrm{S}, \mathrm{W})$ & - \\
\hline Astalotermes near quietus & Soil, Nest (Pseudoecy), runway on tree (W) & - & - \\
\hline Basidentitermes potens Silvestri, 1914 & Nest, soil $(S, W)$ & - & - \\
\hline Cubitermes near proximatus Silvestri, 1914 & Nest, soil $(\mathrm{S}, \mathrm{W})$ & - & - \\
\hline Cubitermes severus Silvestri, 1914 & - & Nest $(S, W)$ & - \\
\hline Noditermes cristifrons (Wasmann, 1911) & Nest $(S, W)$ & Nest $(S, W)$ & Nest, soil $(S, W)$ \\
\hline Amitermes evuncifer (Silvestri, 1912) & Nest, stump $(S, W)$ & Stump, dead wood $(S, W)$ & - \\
\hline Amitermes spinifer (Silvestri, 1914) & - & Nest $(S, W)$ & - \\
\hline Microcerotermes fuscotibialis (Sjöstedt, 1896) & Tree $(S, W)$ & Tree $(S, W)$ & - \\
\hline Microcerotermes near parvulus (Sjöstedt, 1911) & Nest $(S, W)$ & - & - \\
\hline
\end{tabular}




\subsubsection{Odontotermes erraticus Grassé, 1944}

The head of the soldier (Figure 5) is yellow-orange in color or dark-brown. The antennae are with 16 antennal segments. The left mandible shows a marginal tooth. The two soldier head measurements are as follows: head length $1.61 \mathrm{~mm}$ and $1.64 \mathrm{~mm}$, head width $1.27 \mathrm{~mm}$ and $1.28 \mathrm{~mm}$, left mandible length $1.10 \mathrm{~mm}$ and $1.15 \mathrm{~mm}$, hind tibia length $1.09 \mathrm{~mm}$.

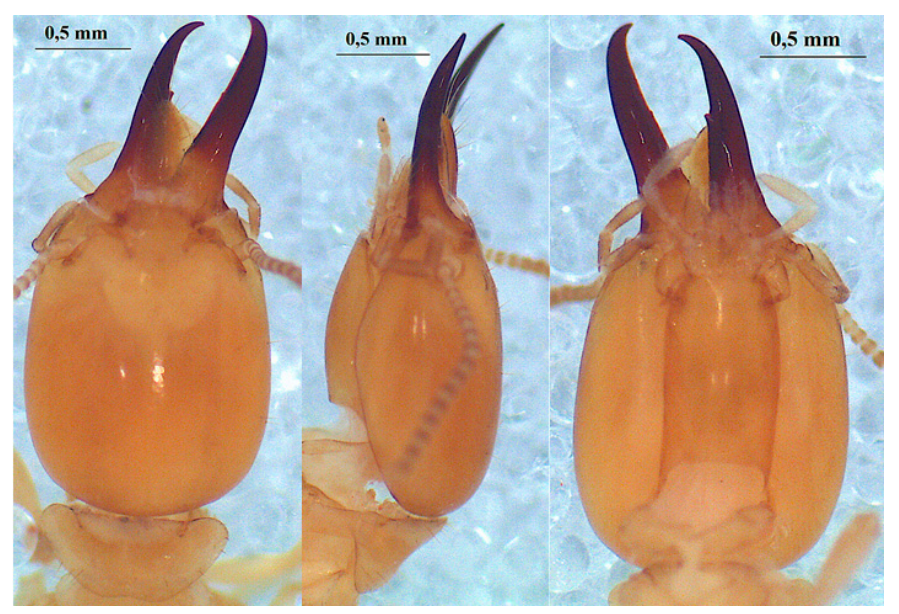

Figure 5. The head of Odontotermes erraticus Grassé 1944 soldier in dorsal (left), profile (middle) and ventral (right) views.

A large worker has 17 antennal segments in their antennae whereas a small worker individual has 16 antennal segments. Head measurements are shown in Tables 6 and 7.

Table 6. The measurements ( $\mathrm{mm}$ ) of the large workers of Odontotermes erraticus Grassé.

\begin{tabular}{cccc}
\hline Worker & Range & Mean & Number \\
\hline Head length & $1.25-1.34$ & 1.29 & 5 \\
\hline Head width & $1.33-1.40$ & 1.36 & 5 \\
\hline Hind tibia length & $1.05-1.11$ & 1.08 & 4 \\
\hline
\end{tabular}

Table 7. The measurements ( $\mathrm{mm}$ ) of the small workers of Odontotermes erraticus Grassé.

\begin{tabular}{cccc}
\hline Worker & Range & Mean & Number \\
\hline Head length & $0.85-0.87$ & 0.86 & 3 \\
\hline Head width & $0.91-0.92$ & 0.91 & 3 \\
\hline Hind tibia length & $0.86-0.88$ & 0.87 & 3 \\
\hline
\end{tabular}

\subsubsection{Cubitermes severus Silvestri, 1914}

This is a species characterized by the shape (Figure 6) and the size (Table 8) of its soldier. Table 9 shows the dimensions of workers. It is the largest size Cubitermes in the collection.

Cubitermes severus has been collected both in nests without caps (Figure 7a) and in typical mushroom nests (Figure 7b). The column of the nest is much higher than that of Cubitermes near proximatus. This mound builder species occupies his nest alone or shares it with the inquilines Promirotermes holmgreni, Noditermes cristifrons and Pericapritermes urgens. 


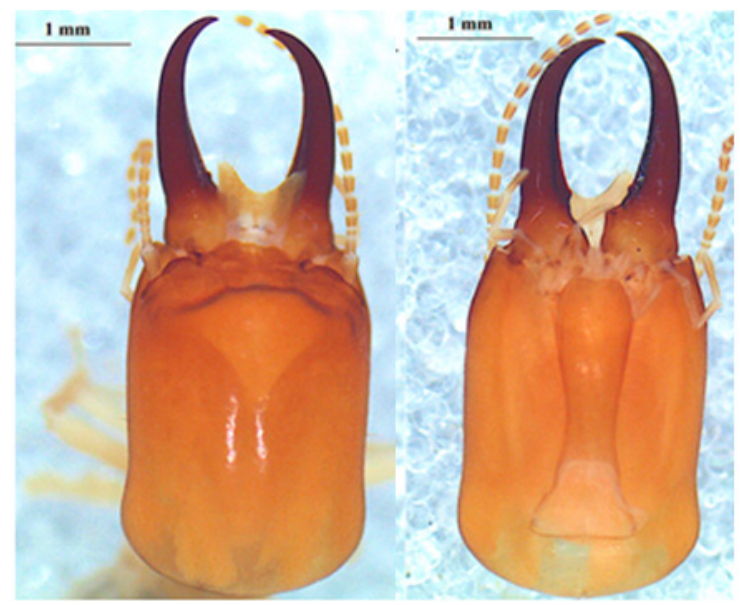

Figure 6. The head of the Cubitermes severus Silvestri 1914 soldier in the dorsal (left) and ventral (right) views.

Table 8. The measurements (mm) of the soldiers of Cubitermes severus Silvestri, 1914.

\begin{tabular}{cccc}
\hline Soldier & Range & Mean & Number \\
\hline Head length & $2.87-3.08$ & 2.99 & 9 \\
\hline Head width & $1.96-2.11$ & 2.03 & 9 \\
\hline Length of left mandible & $1.98-2.03$ & 2.01 & 9 \\
\hline Hind tibia length & $1.57-1.69$ & 1.63 & 8
\end{tabular}

Table 9. The size measurements (mm) of the workers of Cubitermes severus Silvestri, 1914.

\begin{tabular}{cccc}
\hline Worker & Range & Mean & Number \\
\hline Head length & $1.11-1.19$ & 1.14 & 5 \\
\hline Head width & $1.19-1.24$ & 1.21 & 5 \\
\hline Hind tibia length & 1.25 & $1.29-1.27$ & 4 \\
\hline
\end{tabular}

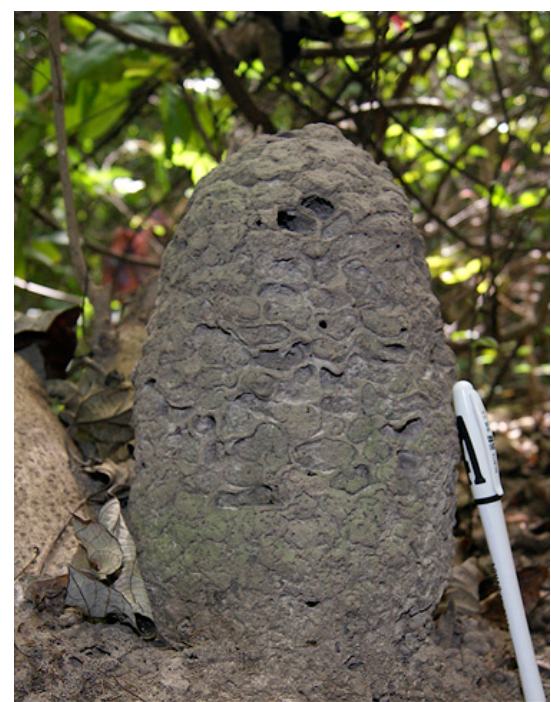

(a)

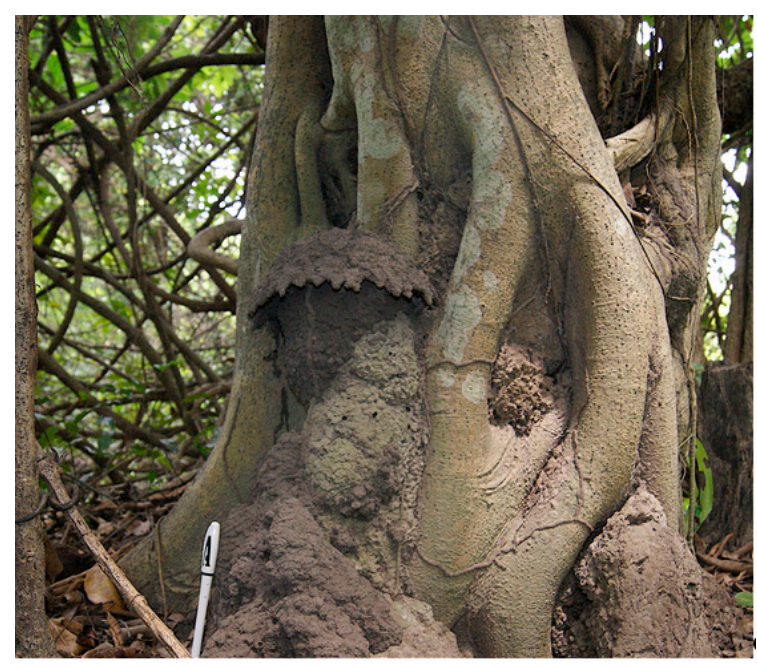

(b)

Figure 7. (a) The nest of the Cubitermes severus Silvestri 1914 without a cap; (b) The nest of Cubitermes severus Silvestri 1914 with a cap. 


\subsubsection{Cubitermes Near proximatus Silvestri, 1914}

The observation of the enteric valves of the workers of these Cubitermes shows their proximity to C. proximatus. However, based on the morphology, the color and the dimensions of the soldier's head, we divided them into two morphotypes.

\section{Morphotype 1 of Cubitermes Near proximatus}

This is a species recognizable by the shape and the ochraceus color of the head of its soldiers (Figure 8). Table 10 shows the dimensions of the soldier and Table 11 shows those of the worker.

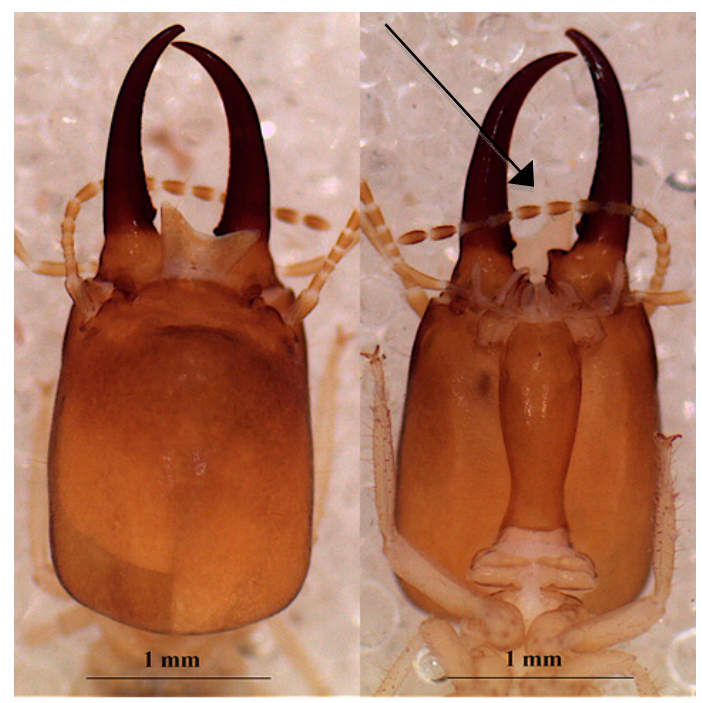

Figure 8. The head of morphotype 1 of Cubitermes near a proximaus Silvestri 1914 soldier in the dorsal (left) and ventral (right) views (the arrow shows the indentation at the base of the mandible).

Table 10. The measurements $(\mathrm{mm})$ of the soldiers of morphotye 1 of Cubitermes near proximatus Silvestri, 1914.

\begin{tabular}{cccc}
\hline Soldier & Range & Mean & Number \\
\hline Head length & $1.76-1.98$ & 1.89 & 8 \\
\hline Head width & $1.37-1.49$ & 1.43 & 8 \\
\hline Length of the left mandible & $1.44-1.50$ & 1.48 & 8 \\
\hline Hind tibia length & $1.14-1.16$ & 1.14 & 4 \\
\hline
\end{tabular}

Table 11. The measurements ( $\mathrm{mm}$ ) of the workers of morphotype 1 of Cubitermes near proximatus Silvestri, 1914.

\begin{tabular}{cccc}
\hline Worker & Range & Mean & Number \\
\hline Head length & $0.82-0.89$ & 0.85 & 4 \\
\hline Head width & $0.93-0.94$ & 0.93 & 4 \\
\hline Hind tibia length & $0.92-0.95$ & 0.94 & 3 \\
\hline
\end{tabular}

\section{Morphotype 2 of Cubitermes Near proximatus}

The soldier of morphotype 2 (Figure 9) is clearly larger (Table 12). Morphologically, differences are noted on the lateral margin of the head, which is less convergent, and the mandibles that are less curved in C. proximatus. The indentations at the base of the mandibles (ventral view of Figures 8 and 9) are also distinctive features between the two morphotypes. 


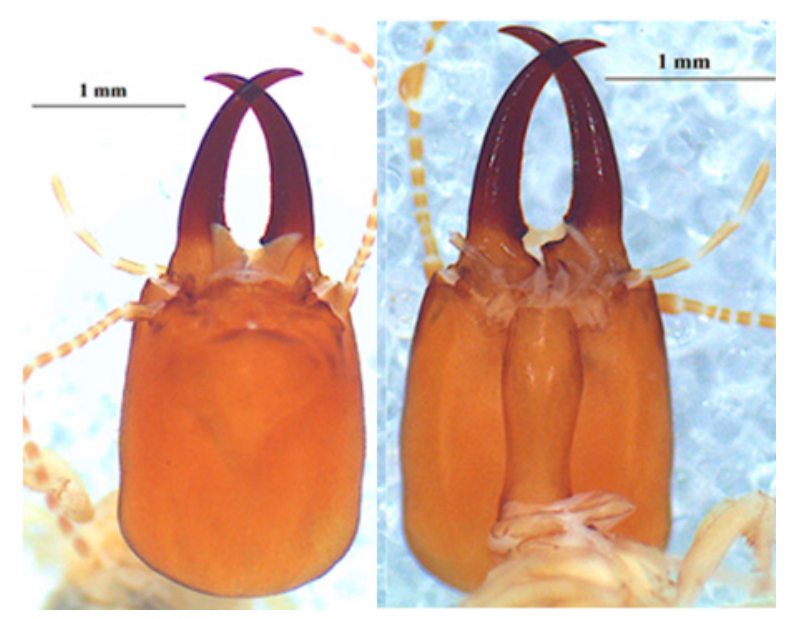

Figure 9. The head of morphotype 2 of Cubitermes near the proximatus Silvestri 1914 soldier in the dorsal (left) and ventral (right) views.

Table 12. The measurements $(\mathrm{mm})$ of the soldiers of morphotype 2 of Cubitermes near proximatus Silvestri, 1914.

\begin{tabular}{cccc}
\hline Soldier & Range & Mean & Number \\
\hline Head length & $2.05-2.19$ & 2.13 & 8 \\
\hline Head width & $1.50-1.65$ & 1.59 & 8 \\
\hline Length of left mandible & $1.60-1.70$ & 1.64 & 8 \\
\hline Hind tibia length & $1.24-1.32$ & 1.28 & 7 \\
\hline
\end{tabular}

The measurements of the morphotype 2 workers are shown in Table 13.

Table 13. The measurements $(\mathrm{mm})$ of the workers of morphotype 2 Cubitermes near proximatus Silvestri, 1914.

\begin{tabular}{cccc}
\hline Worker & Range & Mean & Number \\
\hline Head length & $0.96-1.04$ & 1.04 & 7 \\
\hline Head width & $1.01-1.05$ & 1.03 & 7 \\
\hline Hind tibia length & $0.98-1.01$ & 1.00 & 7 \\
\hline
\end{tabular}

The mushroom nests of morphotype 2 are small in size (Figure 10). The column is often sufficiently developed to allow a clear distinction with the cap. The nests are occupied solely by the builder or shared with inquilines such as Allognathotermes hypogeus, Euchilotermes tensus arcuata, Microtermes grassei and/or Promirotermes holmgreni infera.

\subsubsection{Euchilotermes tensus arcuata Silvestri, 1914}

The head of the Euchilotermes tensus arcuata soldier (Figure 11) is distinctly rectangular in shape and yellowish in color with light brown mandibles. The mandibles are strongly curved. The labrum is long and wide with two apical large and rounded lobes. The measurements of the soldiers are noted in Table 14 and those of the workers in Table 15. 


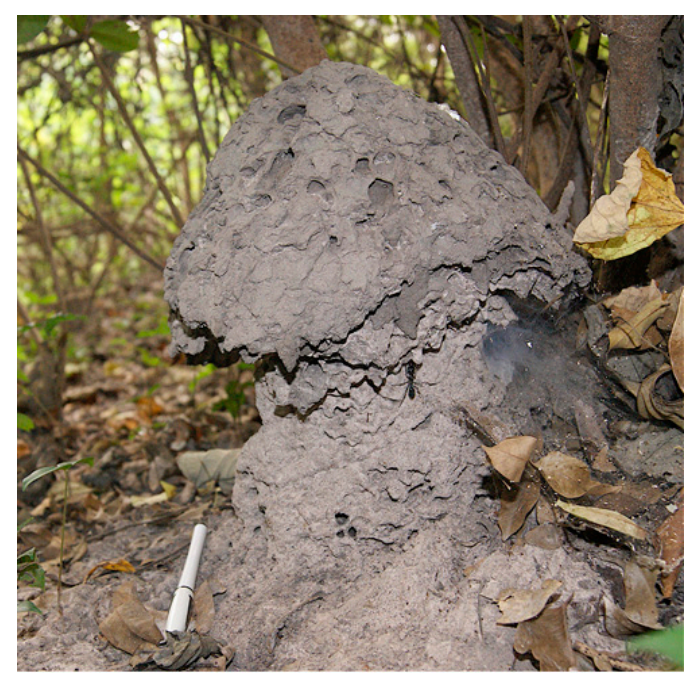

Figure 10. The mushroom nest of Cubitermes near proximatus Silvestri, 1914.

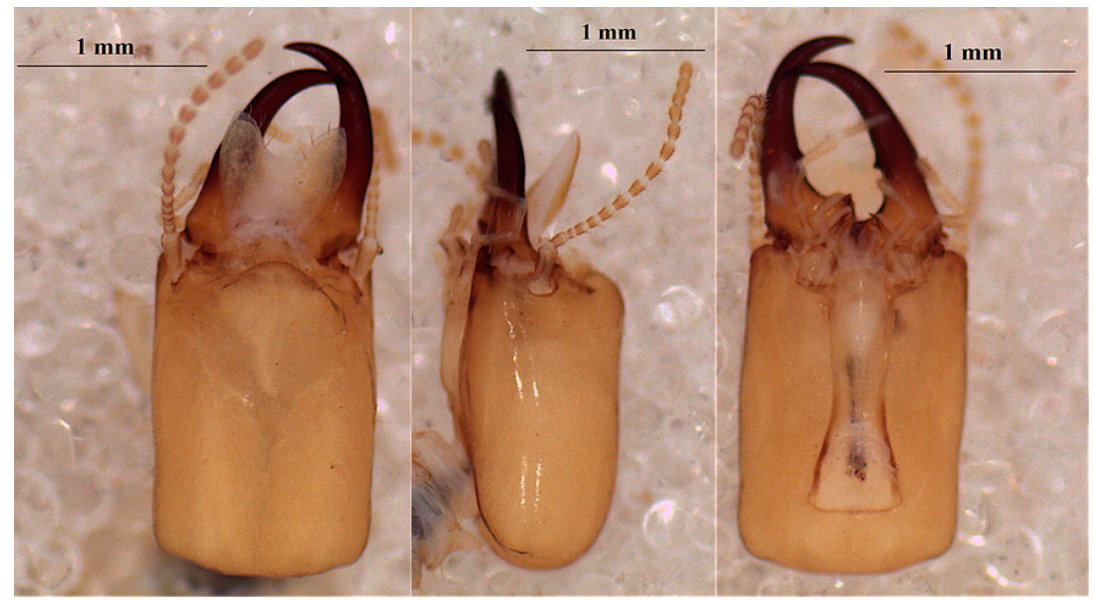

Figure 11. The head of a Euchilotermes tensus arcuata Silvestri 1914 soldier in the dorsal (left), profile (middle) and ventral (right) views.

Table 14. The measurements (mm) of the soldiers of Euchilotermes tensus arcuata Silvestri, 1914.

\begin{tabular}{cccc}
\hline Soldier & Range & Mean & Number \\
\hline Head length & $1.76-1.85$ & 1.82 & 6 \\
\hline Head width & $1.16-1.24$ & 1.21 & 6 \\
\hline Length of left mandible & $1.15-1.19$ & 1.17 & 6 \\
\hline Hind tibia length & $0.89-0.97$ & 0.91 & 6 \\
\hline
\end{tabular}

Table 15. The measurements (mm) of the workers of Euchilotermes tensus arcuata Silvestri, 1914.

\begin{tabular}{cccc}
\hline Worker Individual & Range & Mean & Number \\
\hline Head length & $0.75-0.84$ & 0.79 & 4 \\
\hline Head width & $0.81-0.88$ & 0.84 & 4 \\
\hline Hind tibia length & $0.77-0.84$ & 0.81 & 4 \\
\hline
\end{tabular}

\subsubsection{Basidentitermes sp.}

The specimens so designated seem different from all known species of the genus. However, more specimens, particularly of soldiers, are needed before the description of a new species. 
3.6.6. Noditermes cristifrons (Wasmann, 1911)

The measurements of the soldiers of Noditermes cristifrons are recorded in Table 16.

Table 16. The measurements ( $\mathrm{mm}$ ) of the soldiers of Noditermes cristifrons (Wasm.).

\begin{tabular}{cccc}
\hline Soldier & Range & Mean & Number \\
\hline Head length & $1.16-1.32$ & 1.24 & 15 \\
\hline Head width & $1.00-1.10$ & 1.04 & 15 \\
\hline Length of left mandible & $1.30-1.46$ & 1.38 & 15 \\
\hline Hind tibia length & $0.76-0.82$ & 0.80 & 8 \\
\hline
\end{tabular}

The nests of Noditermes cristifrons (Figure 12) are free standing or backed to a tree which affects, in this case, the shape. However, in both cases, the nest displays a scaly appearance. Noditermes cristifrons occupies its nest alone or shares it with Pericapritermes urgens.

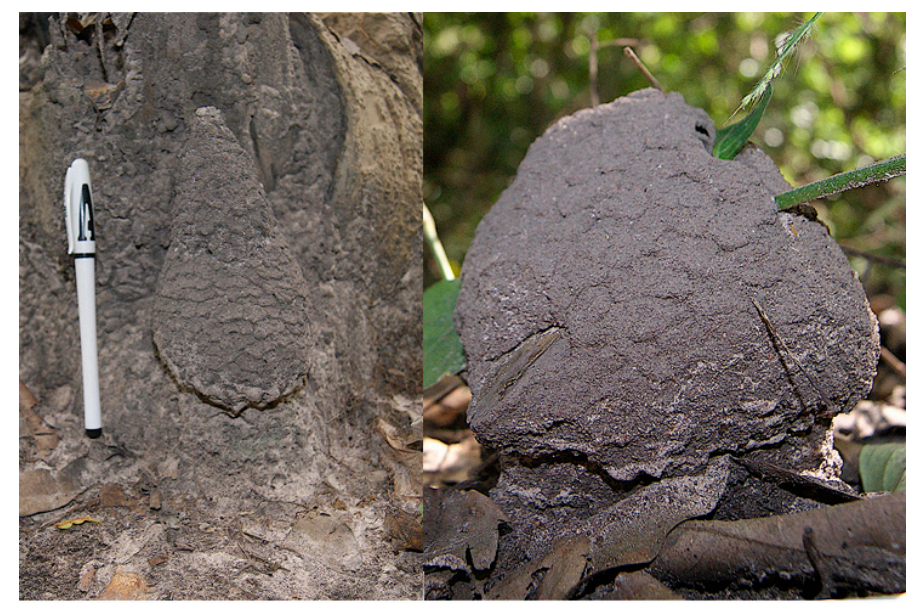

Figure 12. Noditermes cristifrons: tree trunk-backed nest (left); freely standing nest (right).

\section{Discussion}

The compilation of the references on the termites of The Gambia gives 30 species for this country. The present study has extended the number of termite species recorded from The Gambia to forty-six (46). Among the thirty-one (31) species that have been newly collected, nineteen (19) species are new for The Gambia and one species among the set is probably new with this field in science.

In Benin, Attignon et al. [21], using the Jones et al. sampling protocol [10], recorded 17 termite species in semi-deciduous forests and 10 species in teak plantations. In a savannah in northern Togo, with the same sampling method, 19 termite species were identified [22].

The protection of sites in The Gambia would explain the greater diversity of their termite fauna. However, in Senegal, in the Kolda region [23] (bordering inner Gambia in the south-east), except for Apicotermitinae, two species of Basidentitermes, Euchilotermes tensus arcuata and Amitermes spinifer, all of the other species recorded in Abuko, Nyambai and Tanji are found.

Of the thirty-one (31) species recorded during this study, only morphotype 2 of Cubitermes sp. near proximatus and Euchilotermes arcuata are not known in Senegal. Morphotype 1 of Cubitermes sp. near proximatus recorded in Senegal $[24,25]$ was identified as C. bilobatodes. Cubitermes severus occurs exists in Casamance, Senegal, but has been cited by misidentification as C. fungifaber [25].

Odontotermes erraticus, described from Niger by Grassé [17], was indeed supposed to be restricted to Niger [4]. Ndiaye [25] points out for the first time its occurrence in Senegal. As one of the newly added species to Gambia's termite, its presence is seemingly throughout West Africa. O. erraticus would be widespread in the Sudano-Sahelian zones of West Africa. Its presence was probably hidden 
by numerous misidentifications, particularly confusions with the species $O$. vulgaris and O. latericius of southern Africa. As Ruelle [26] pointed out, the genus Odontotermes is the most complex of the Macrotermitinae.

The genus Euchilotermes, exclusively known in the Ethiopian region, comprises four described species [4]. E. quadriceps described by Emerson [13] is known in Congo-Zaire (now RD Congo) and Malawi. E. umbraticola described by Williams [27,28] is a species of East Africa (Kenya, Tanzania) [4]. Silvestri described E. tensus var. acutidens and E. tensus var. arcuata [13]. The variety acutidens has been elevated to the rank of species by Emerson [14] on the basis of the following differences: "mandibles more prolonged and curved at apex than with $M$. tensus, the teeth are smaller and sharper with a wider gula".

According to Krishna et al. [4], Microtermes hollandei Grassé is put in synonymy with M. lepidus Sjöstedt by Emerson (unpublished catalog). This synonymy is fully justified based on the perfect resemblance between the two species. Grassé [14], the author of the original provisional description of M. hollandei, found the differences between the two species as minor and explained them by geographical distribution. However, it should be noted that for both M. lepidus [29] and M. Hollandei [14], the specimens used in the original description are all from Dakar, Cap vert region, Senegal.

Microcerotermes fuscotibialis is easily distinguished by the morphology, the size and the ecology from M. solidus, M. parvus, and M. parvulus which are referred to as small Microcerotermes [21]. The difficulties in the discrimination of these small Microcerotermes are the source of multiple misidentifications. Described from tropical Africa and cited from all African regions, M. parvulus was also recorded from Saudi Arabia [30]. This wide distribution can be explained by the strong plasticity of the species or due to misidentification; the most likely hypothesis. As noted by several authors $[24,25,31,32]$, we believe that the revision of the African Microcerotermes is necessary.

\section{Acknowledgments}

This research work was funded by the West African Economic and Monetary Union (UEMOA). We are very grateful to Guy Josens (Université Libre de Bruxelle) for his enlightened remarks on the identification of the Cubitermes species.

Author Contributions: Conceptualization A.B.N., E.N.; Methodology, A.B.N.; Investigation, A.B.N., E.N., P.A.C.; Validation, A.B.N., E.N., P.A.C.; Formal Analysis, A.B.N., E.N., P.A.C.; Investigation, A.B.N., E.N., P.A.C.; Ressources, A.B.N., E.N., P.A.C.; Data curation, A.B.N.; Writing-Original Draft, A.B.N.; Writing-Review, A.B.N., E.N., P.A.C.; Visualization, A.B.N.; Supervision, A.B.N.; Project Administration, A.B.N.; Funding Acquisition, A.B.N.

Conflicts of Interest: The authors declare no conflict of interest.

\section{References}

1. Sands, W.A. New species and records of Nasutitermitinae (Isoptera: Termitidae) from Africa. Proc. R. Entomol. Soc. Lond. 1968, 37, 163-169. [CrossRef]

2. Snyder, T.E. Catalog of the termites (Isoptera) of the World. In Smithsonian Miscellaneous Collections; Smithsonian Institution: Washington, D.C., USA, 1949; Volume 112, pp. 1-493.

3. Sjöstedt, Y. Revision der Termiten Afrikas. 3. Monographie. In Kungl Svenska Vetenska Akademiens Handlingar; Almqvist \& Wiksells Boktryckeri-A.-B.: Stockholm, Sweden, 1925; Volume 3, pp. 1-435.

4. Krishna, K.; Grimaldi, D.A.; Krishna, V.; Engel, M.S. Treatise on the Isoptera of the World. 4. Termitidae (part one). In Bulletin of the American Museum of Natural History; American Museum of Natural History: New York, NY, USA, 2013; Volume 377, pp. 1-2704.

5. Sands, W.A. The soldierless termites of Africa (Isoptera, Termitidae). In Bulletin of the British Museum (Natural History) Entomology, Supplement; British Museum: London, UK, 1972; Volume 18, pp. 1-244.

6. Sands, W.A. New genera and species of soil feeding termites (Isoptera: Termitidae) from African savannas. J. Nat. Hist. 1995, 29, 1483-1515. [CrossRef]

7. Sands, W.A. The Identification of Workers Castes of Termites Genera from Soils of Africa and the Middle East; Cab International: Wallington, UK, 1998; 500p. 
8. Williams, R.M.C.; Perez-Morales, J.V. The effect of group size on the survival and feeding economy of pseudoworkers of building damaging Cryptotermes spp. (lsoptera, Kalotermitidae). In Social Insects in the Tropics; Jaisson, P., Ed.; Presses de I’Université Paris Xll: Paris, France, 1983; Volume 2, pp. 219-234.

9. Johnson, R.A.; Lamb, R.W.; Sands, W.A.; Shittu, M.O.; Williams, R.M.C.; Wood, T.G. A check list of Nigerian termites (Isoptera) with brief notes on their biology and distribution. Niger. Field 1980, 45, 50-64.

10. Jones, D.T.; Eggleton, P. Sampling termite assemblages in tropical forests: Testing a rapid biodiversity assessment protocol. J. Appl. Ecol. 2000, 37, 191-203. [CrossRef]

11. Silvestri, F. Termitidi raccolti da L. Fea alla Guinea Portoghese e alla Isole, S. Thomé, Annobon, Principe e Fernando Poo. Annali Museo Civico di Storia Naturale di Genova 1912, 45, 211-255.

12. Silvestri, F. Contribuzione alla conoscenza dei Termitidi e Termitophili dell'Africa occidentale. I. Termitidi. Bolletino del Laboratorio di Zoologia Generale e Agraria della R Scuola Superiore d'Agricoltura 1914, 9, 1-146.

13. Emerson, A.E. Termites of the Belgian Congo and the Cameroon. Bull. Am. Mus. Nat. Hist. 1928, 57, $212-222$.

14. Grassé, P.P. Recherches sur la systématique et la biologie des termites de l'Afrique occidentale française. Première partie: Protermitidae, Mesotermitidae et Metatermitidae (Termitinae). Annales de la Société Entomologique de France 1937, 106, 1-100.

15. Grassé, P.P. Recherches sur la biologie des termites champignonnistes (Macrotermitinae). Annales des Sciences Naturelles 1944, 6, 97-171.

16. Bouillon, A.; Mathot, G. Quel est ce termite africain? Zooleo 1965, 1, 1-115.

17. Roy-Noël, J. Le parc national du Niokolo-Koba. VIII. Isoptera. Mémoire de l'IFAN 1969, 84, 113-178.

18. Sands, W.A. A revision of the Termites subfamily Nasutitermitinae (Isoptera): Termitidae from the Ethiopian region. In Bulletin of the British Museum (Natural History) Entomology, Supplement 4; Bristih Museum: London, UK, 1965; Volume 4, pp. 1-172.

19. Sands, W.A. The Termites Genus Amitermes in Africa and the Middle. Nat. Resour. Inst. Bull. 1992, 51, 1-140.

20. Josens, G. Bilingual key of the West African Cubitermes soldiers and workers. In Taxonomy of West African Termites: Challenges and Prospects; University of Freiburg: Freiburg, Germany, 2008; 8p.

21. Attignon, S.E.; Lachat, T.; Sinsin, B.; Nagel, P.; Paveling, R. Termite assemblages in a West-African semideciduous forest and teak plantations. Agric. Ecosyst. Environ. 2005, 110, 318-326. [CrossRef]

22. Schyra, J.; Korb, J. Termites Communities along a Disturbance Gradient in a West African Savanna. Insects 2019, 10, 17. [CrossRef]

23. Sane, H.; Samb, T.; Ndiaye, A.B.; Ba, C.T. Etude De La Diversite Des Termites (Isoptera) Dans Quelques Localites De La Region De Kolda (Haute Casamance, Senegal). Eur. Sci. J. 2016, 12, 1857-7881. [CrossRef]

24. Roy-Noël, J. Recherches sur l'écologie des Isoptères de la presqu'île du Cap-Vert (Sénégal). Bulletin IFAN Série A 1974, 26, 292-609.

25. Ndiaye, A.B. Contribution à la Connaissance des Termites (Isoptera Brullé, 1832) du Sénégal: Systématique et Écologie. Partie, I. Systématique. Ph.D. Thesis, Université Ch. A. Diop, Dakar, Sénégal, 2014; 257p.

26. Ruelle, J.E. Isoptera. In Biogeography and Ecology of Southern Africa; Werger, M.J.A., van Bruggen, A.C., Dr, W., Junk, B.V., Eds.; DR. W. JUNK b. v. Publishers: The Hague, The Netherlands, 1978; pp. 748-762.

27. Williams, R.M.C. New Est African Termitinae (Isoptera: Termitidae). Proc. R. Entomol. Soc. Lond. B 1954, 23, 215-227.

28. Williams, R.M.C. A correction Concerning two East African Termitinae (Isoptera: Termitidae). Proc. R. Entomol. Soc. Lond. B 1962, 31, 127-130. [CrossRef]

29. Sjöstedt, Y. Weitere Neuheiten von der afrikanischen Termitenfauna. Rev. Zool. Afr. 1924, 12, $495-497$.

30. Faragalla, R.A.A.; Al Qhtani, M.H. The Urban termite fauna (Isoptera) of Jeddah City, Western Saudi Arabia. Life Sci. J. 2013, 10, 1695-1701.

31. Noirot, C. Termites du centre et du sud-ouest de l'Angola récoltés par A. de Barros Machado. Publiçaões Culturais de Companhia Diamantes de Angolas 1955, 27, 139-150.

32. Josens, G. Etudes Biologique et Écologique des Termites (Isoptera) de la Savane de Lamto-Pakobo (Côte d'Ivoire). Ph.D. Thesis, Université Libre de Bruxelles, Brussels, Belgium, 1972; 262p.

(C) 2019 by the authors. Licensee MDPI, Basel, Switzerland. This article is an open access article distributed under the terms and conditions of the Creative Commons Attribution (CC BY) license (http://creativecommons.org/licenses/by/4.0/). 